\title{
RAPTOR ELECTROCUTIONS AND ASSOCIATED FIRE HAZARDS IN THE SNAKE RIVER BIRDS OF PREY NATIONAL CONSERVATION AREA
}

\author{
Challenge Cost Share \\ Annual Report
}

Submitted to

U.S. Bureau of Land Management

Lower Snake River District

3948 Development Ave.

Boise, ID 83705
Idaho Power Company

1221 W. Idaho St.

Boise, ID 83702

\author{
Submitted by \\ Robert N. Lehman \\ Justin S. Barrett \\ USGS/Biological Resources Division \\ Forest and Rangeland Ecosystem Science Center \\ 970 Lusk St. \\ Boise, ID 83706
}

February 2000 
ABSTRACT: In 1999, we began an assessment of raptor electrocutions on power lines in and near the Snake River Birds of Prey National Conservation Area (NCA) in southwestern Idaho. The study will allow us to estimate electrocution rates, identify electrocution hazards, and ultimately develop a program to reduce power line-related mortality and fire hazards in the NCA. This year, we produced a distribution line map of the study area, selected study segments, and began searching for dead raptors along 19 segments totaling 61.2 linear $\mathrm{km}$. Study segments are located in the relatively undeveloped interior of the NCA, and along the borders and private inholdings of the NCA where agriculture and associated power line developments are common. From September-November, we visited all study segments to remove remains of birds killed prior to this study. We found partially intact skeletons, scattered bones, and feathers of at least 19 birds during these searches. In December, we began sampling for recent kills and found five dead birds. Of the 24 birds found during both surveys, we were able to identify 6 common ravens (Corvus corax), 2 red-tailed hawks (Buteo jamaicensis), 2 American kestrels (Falco sparverius), 1 northern harrier (Circus cyaneus), 1 golden eagle (Aquila chrysaetos), and 1 barn owl (Tyto alba). Only the golden eagle showed clear signs of electrocution, but most remains were too old to establish cause of death. All 24 sets of remains were found under 21 poles. We found dead birds under 18 tangent poles and 3 poles in deadend and corner positions. Pole-top configurations included simple crossarm, underbuilt, compact, and $\mathrm{H}$-frame designs. Additional hardware items on many poles included exposed jumper wires, transformers, capacitors, and electrical switches of several kinds. In 2000, we will continue sampling study segments each month until a full year of sampling has been completed. This will allow detection of seasonal differences in electrocution rates during three raptor concentration periods--nesting, postfledging, and wintering. 


\section{INTRODUCTION}

The Snake River Birds of Prey National Conservation Area (NCA) in southwestern Idaho supports one of the highest densities of non-colonial nesting raptors in the world (U.S. Dept. Int. 1979, Olendorff et al. 1989). The area supports 15 nesting species, and an additional 10 species during migration and winter. Because of its importance, Congress provided permanent protection to the area in August 1993.

One of the most important management issues in the NCA is the conversion of native shrub habitats to non-native annual grasslands due to wildfires. During the late 19th century, exotic annual plants--most notably cheatgrass (Bromus tectorum)--began to invade the American West (Yensen 1981). Cheatgrass grows in dense patches, dries out earlier than native bunchgrasses during the summer, and is highly flammable (Pellant 1990, Peters and Bunting 1994). As a result, wildfires in infested areas today are more frequent and burn larger areas than under native conditions (Whisenant 1990). These altered fire conditions have led to conversion of $>50 \%$ of the NCA's native plant communities (Kochert and Pellant 1986, U.S. Dept. Int. 1995).

A separate but related issue in the NCA is electrocution of raptors on power lines. Typically, raptor electrocutions occur on distribution lines (as opposed to transmission lines) which transmit electricity at voltages $<69 \mathrm{kV}$ to residences and other individual users (APLIC 1996, Lehman 1999). Distribution lines have low clearances between energized components allowing simultaneous contact with conductors and/or ground wires by the wings and body parts of large birds. Habitat conversions and raptor electrocutions are linked because electrocuted birds are a possible source of fire ignitions. Currently, little is known about electrocution risks in the NCA. What is known is that electrocution of large birds, including raptors, common ravens (Corvus corax), and great blue herons (Ardea herodius) have resulted in at least 26 fire starts in BLM's Lower Snake River District since 1976 (U.S. Dept. Int. unpubl. data). Six of these were in the NCA; and one, the 3,700-ha Sinker Butte Fire, destroyed a significant portion of the NCA's remaining shrub lands in 1996.

Recent studies indicate that habitat conversions due to wildfires, in combination with other disturbances, are having serious effects on some raptor species in the NCA. The golden eagle (Aquila chrysaetos) and prairie falcon (Falco mexicanus), in particular, have experienced significant population declines in recent years (Steenhof et al. 1997, Lehman et al. 1998, Steenhof et al. 1999). Thus, it is critical that human-caused mortality of raptors and fire ignitions in the NCA be controlled when possible. In 1999, we began a study to assess raptor electrocution rates and identify electrocution hazards in and near the NCA. Eventually, this will allow the Idaho Power Company to develop a program for mitigating raptor electrocutions. A consequence of that program will be a reduction of both power line-related mortalities and fire hazards. Here, we report on progress made in 1999 and outline plans for 2000. 


\section{OBJECTIVES}

Our goal is to reduce electrocution risks and fire hazards in the NCA by identifying specific poles and pole designs that are hazardous to raptors and other large birds.

Specific objectives of the study are:

1) Estimate raptor electrocution rates (deaths $/ \mathrm{km} / \mathrm{month}$ ) along selected stretches of distribution lines.

2) Identify hazardous pole designs and compare electrocution rates (deaths/pole/month) among pole types.

3) Evaluate fire hazards along all distribution lines sampled.

4) Evaluate ecological and other factors that may contribute to electrocution hazards in the NCA.

\section{STUDY AREA}

Our research was conducted on the benchlands north of the Snake River Canyon, Ada and Elmore Counties, Idaho $\left(43^{\circ} \mathrm{N}, 116^{\circ} \mathrm{W}\right)$ (Fig. I ). The study area included public and adjacent private lands. Topography on the benchlands is flat to slightly rolling with scattered, isolated cinder cones and buttes. Elevation ranges from $920 \mathrm{~m}$ at the canyon rim to $1,066 \mathrm{~m}$ at the highest point. Vegetation in undisturbed areas is dominated by big sagebrush (Artemisia tridentata), shadscale (Atriplex confertifolia), winterfat (Krascheninnikovia lanata), and other shrub species (Kochert and Pellant 1986). In areas where surface-disturbing activities or wildfires have occurred, vegetation is dominated by cheatgrass (Bromus tectorum), Russian thistle (Salsola kali), and other non-native annual plants (Yensen 1982). Primary land uses in and adjacent to the NCA include farming, grazing, outdoor recreation, and military training (U.S. Dept. Int. 1995). Approximately 17,982 ha of privately owned land within the NCA boundaries, and many private holdings outside the NCA, have been developed for agriculture, primarily irrigated cropland and pasture (U.S. Dept. Int. 1996). Sugar beets, corn, grain, alfalfa, beans, and potatoes are the principle crops grown in the area. Military training occurs in a 56,022-ha Idaho Army National Guard training site contained entirely within the study area, and includes artillery firing, armored vehicle training, and small arms firing (U.S. Dept. Int. 1996). There are no power line developments associated with the training area.

\section{METHODS}

To assess electrocution risks and estimate rates of electrocution, we searched for dead birds along selected power line stretches in and near the NCA. We sampled in two areas: the relatively undeveloped interior of the NCA; and along the borders of the NCA where private inholdings and associated power line developments are common. Our intent was to sample selected stretches (hereafter called study segments or study sites) in both areas each month for 12 months. This 
allowed detection of differences in electrocution rates in developed and undeveloped areas, as well as seasonal differences during three raptor concentration periods--nesting, postfledging, and wintering. In developed areas, we focused on agricultural developments (irrigated cropland and pasture), because raptors often are observed foraging in these areas (U.S. Dept. Int. 1996), and presumably often use power poles as hunting perches.

In 1999, we produced a distribution line map of the NCA, selected study segments, and began sampling for dead raptors along those segments. To produce the power line map, we used an ARC/INFO Geographic Information System (GIS) (Environmental Systems Research Inc. 1993) to overlay a distribution line grid, provided by Idaho Power, onto a map of the NCA showing landownership, roads, and major topographic features. The distribution grid showed the configuration of 1-phase, 2-phase, and 3-phase lines. During August and September, we randomly checked the accuracy of the distribution grid to establish that power lines were correctly shown and to assess which inholdings contained agricultural developments. Some power lines were added to the grid as a result of ground truthing efforts.

The completed power line map showed that most distribution lines in and near the NCA are 3 -phase lines. Two-phase lines are rare, and 1-phase lines usually consist of short $(<1 \mathrm{~km})$ feeder lines to private farms and residences. As a result, we limited power line searches to 3-phase lines. The map also showed that 3-phase lines bordering the NCA consist of many relatively short stretches that follow county roads and other public and private thoroughfares. In contrast, 3-phase lines penetrating the interior of the NCA consist of a few relatively long, unbroken stretches connecting production facilities and substations to distribution networks outside the NCA.

To select interior study sites, we delineated all 3-phase distribution lines within the boundary of the NCA into segments of varying lengths depending on landownership and patterns of agricultural development. To be included as a possible study site, a segment had to be at least $2 \mathrm{~km}$ long and both end points had to lie $\geq 1 \mathrm{~km}$ from the NCA boundary, or in the case of private inholdings, $\geq 1 \mathrm{~km}$ from any agricultural development. This allowed us to retain segments near undeveloped private inholdings. Four segments ranging in length from 2.3-15.9 $\mathrm{km}$ satisfied these criteria. We selected all four as study segments (Table 1, Fig. 1). From 28 September-6 November, we visited each segment to remove the remains of birds killed prior to this study. We sampled the segments (the first of 12 planned sampling bouts) from 9-14 December.

To select border sites, we delineated most 3-phase distribution lines on and near the NCA boundary, and those in and adjacent to inholdings within the NCA, into 2-km-long segments. We considered segments outside the NCA as potential study sites if at least one endpoint was $\leq 2$ $\mathrm{km}$ from an NCA boundary. We considered segments inside the NCA if no part of the segment

extended $>1 \mathrm{~km}$ into the NCA. This prevented overlap of border and interior sites. To be considered, each 2-km segment had to occur $\leq 1 \mathrm{~km}$ from an agricultural development. Seventy- 
two segments met the selection criteria. These were randomly ordered and assigned to a primary list of 15 study segments and a back-up list of 57 segments. From 29 October to 21 November, we attempted to contact private landowners and visited each of the 15 primary sites to remove any bird remains present. We rejected four segments from the primary list because landowners denied us access or could not be located. Two additional segments were rejected because Idaho Power modified poles in these segments after sampling had begun. To ensure a minimum sample size of 15 study segments, we selected six replacement sites from the backup list in the original random order. All 15 study sites (plus the two that were later rejected) were sampled from 1-27 December.

Search areas within study segments consisted of a circular plot with a 10 m radius centered on each power pole. There was no minimum or maximum search time; we searched each plot until we felt that all carcasses had been found. When carcasses were found, we attempted to determine cause of death visually by the presence of burned feathers or feet, gunshots wounds, or other distinguishing marks. All carcasses were collected for later identification to species. We recorded the pole-top configuration for all poles where dead birds were found, and in each case photographed the pole. Pole-top configurations were distinguished by conductor configuration, grounding hardware design, and the presence of jumper wires and additional hardware (e.g., transformers, electrical switches, reclosers, cutout arrestors).

To assess fire hazards and determine if electrocution rates vary by habitat type, we characterized vegetation within a $100 \mathrm{~m}$ wide strip on both sides of each study segment. This allowed an assessment of fire risk at each study site and a determination of how well the surrounding vegetation might propagate afire after ignition. We classified vegetation within the strips as shrubland, disturbed/grassland, mixed shrub/grassland, recent bum (still blackened), bare ground, or greenstrip. We defined areas in which percent cover of shrubs was $\geq 60 \%$ as shrub sites. Areas where percent cover of native and non-native grasses was $\geq 60 \%$ were classified as disturbed/grassland sites. Areas where shrub and grass cover was about the same were classified as mixed shrub/grassland sites.

\section{RESULTS}

\section{$\underline{\text { Raptor Mortalities }}$}

During initial searches of the 19 study segments we found the remains of 19 birds under distribution lines in and near the NCA (Table 2). Most remains were highly weathered, indicating that they had been present for some time. Typically, remains consisted of partially intact skeletons, scattered bones, and varying numbers of feathers (Appendix I). As a result, we could not be certain of the number of individuals present, and 19 represents the minimum number of individuals found. In one case, we found nearly an entire skeleton, and in seven cases skulls or parts of skulls were present.

We found the remains of five birds during our first sampling effort in December. Presumably, 
these birds died after our initial visits from September to November. Only one of these carcasses was fully intact. Remains of the other four birds included partial collections of bones and feathers.

Identification of remains from the September-November survey was difficult because most lacked key skeletal features (e.g., skulls), and feathers usually were highly weathered. We were able to identify 5 common ravens, 1 red-tailed hawk (Buteo jamaicensis), 1 American kestrel (Falco sparverius), and 1 barn owl (Tyto alba). All unidentified remains from this survey were placed in 1 of 4 categories: unidentified bird, unidentified raptor, unidentified hawk, or unidentified eagle (Table 2, Appendix I). Remains from the December survey were fresher, which facilitated identification. Among these were 1 common raven, 1 American kestrel, 1 red-tailed hawk, 1 northern harrier (Circus cyaneus), and 1 golden eagle.

Of 19 individuals found during the September-November survey, nine were found in study segments on the NCA's border, and ten were found in the NCA's interior (Table 2). In December, all five dead birds were found at border sites. Because of advanced decomposition and weathering of remains, cause of death was impossible to determine for birds found during the initial survey. Of five birds found during the December survey, only one showed obvious signs of electrocution. This bird, a golden eagle, had burn marks on its breast and one wing.

\section{$\underline{\text { Pole Type and Configuration }}$}

All 24 sets of remains were found under 21 poles. In three cases, we found two sets of remains under the same pole. We found dead birds under 18 tangent poles and three poles in deadend and corner positions. Among these poles, hardware design (pole-top configuration, grounding, and related hardware) varied widely (Table 3 ). We found birds under poles with four basic pole-top designs: simple crossarm, underbuilt, compact, and H-Frame (Table 3). Eight poles had one crossarm (simple cross arm design) and nine had underbuilt designs with one or two additional crossarms (with and without other hardware). The remaining four poles had either H-Frame or compact designs.

Grounding hardware usually consisted of aground wire extending vertically up the pole to a horizontal neutral line (19 poles). On nine poles, the neutral line was attached to the pole itself, well below any crossarms present. On ten poles, the neutral line was supported on the lowest crossarm, usually alongside energized conductors. In four cases, no neutral line was present. In three of these cases, the groundwire terminated below a single crossarm and was wrapped around the pole. In one case (an H-Frame design), aground wire extended to the top of each pole and ended above the single crossarm.

Additional hardware items, including exposed jumper wires, pole-top switches, fuse disconnect switches, transformers, and capacitors, were present on 13 poles (Table 3). Seven of these poles had exposed jumper wires. In three cases the jumper wires connected energized conductors on corner and deadend poles. The remaining four cases involved transformer poles. In each case jumper wires connected the conductors to transformers mounted on the poles. One of the 
transformer poles also had a capacitor bank, and three had fuse disconnect switches. Finally, pole-top switches were present on two poles that had no additional hardware.

\section{Habitat Types}

At border sites, agriculture was the most frequent habitat feature recorded (Table 1 ). Fourteen of 15 border sites were directly adjacent to croplands or irrigated pasture. In 13 cases, agriculture was the dominant habitat type. However, other habitat types, including shrubland, disturbed/grassland, and mixed shrub/grassland were intermixed with agriculture in most cases.

As expected, we recorded no agricultural developments at the four interior sites (Table 3). Shrublands predominated at two of these sites, and mixed shrub/grassland predominated at one site. The fourth interior site showed a mixture of habitat types. In this case, the longest of the four interior sites, shrublands, disturbed/grasslands, and mixed shrub/grasslands all occurred within the study segment.

\section{DISCUSSION AND PLANS FOR 2000}

Our results indicated that mortality of raptors and ravens on power lines in and near the NCA occurs at least occasionally. However, any conclusions regarding electrocution mortality would be premature. We completed only 1 of 12 planned sampling bouts, and to date only one electrocution mortality has been confirmed. Some of the birds we found dead under power lines in the NCA may have been shot. In several cases, we found spent shell casings near poles where dead birds were found. Other birds in our samples may have been killed by moving vehicles, and a few could represent prey items. We assume that cause of death and identification of remains will be easier as sampling continues, since carcasses will tend to be fresher than those found during preliminary visits.

Fire risk appears to be greatest in the interior of the NCA. Here, power lines tend to occur within stands of native and nonnative plant communities that are naturally vulnerable to wildfires during the dry season (summer and early fall). In contrast, at border sites irrigated agricultural is common and fire risks are relatively low. We are particularly concerned about electrocution risks and fire hazards at two interior sites (Victory and Swan Falls) where many of the remaining stands of native shrubs in the NCA occur (U.S. Dept. Int. 1996). These two sites also are near reaches of the Snake River Canyon where raptor population densities are very high. During searches of these two study segments in 1999, we found the remains of five birds (Appendix I). This indicates that electrocution along these power line stretches may occur from time to time. The combination of high raptor densities and electrocution potential could set the stage for loss of these shrublands to wildfires.

In 2000, we will continue sampling all 19 study segments each month. Sampling will continue at least through November 2000. We are considering adding additional border sites in the 
northwestern corner of the NCA, where two study segments were rejected because Idaho Power began retrofitting the poles after sampling had begun. Unfortunately, the random order of backup sites for these segments resulted in their replacement by sites in the eastern portion of the NCA, where most of our border sites already were concentrated. We feel there should be a better distribution of study segments in this area, given potentially heavy use by raptors. In addition, we will replace one border site in the northeastern corner of the study area because it is in fact a 1-phase line mistakenly shown as a 3-phase line on the power line map used to select study segments. We learned of this error after sampling had begun and data analysis for this report had been completed.

In 2000, we will also continue attempts to identify remains of birds collected in 1999, and to improve our ability to identify remains in the future. We will contact universities in nearby western states to determine if avian bone collections might be available for cross referencing with the skeletal remains of birds recovered during our study. Boise State University has no such collection, but does have a good collection of raptor study skins which can be used to identify feather remains. We will also contact appropriate facilities (e.g., the FWS National Wildlife Health Lab) to arrange for necropsies of fresh carcasses for which cause of death cannot be determined.

Finally, in 2000 we will begin assessing factors that may affect electrocution risk in the NCA and our ability to estimate electrocution rates, per the methodology outlined in our original proposal. Factors we will consider include relative use of selected study segments by raptors, removal of carcasses by scavengers, habitat type, weather, and human development patterns in and around the NCA. 


\section{LITERATURE CITED}

Avian Power Line Interaction Committee (APLIC). 1996. Suggested practices for raptor protection on power lines--the state of the art in 1996. Edison Electric Inst., Raptor Res. Found., Washington, D.C. 148 pp.

Environmental Systems Research Inc. 1993. ARC/INFO ver. 6.11. Redlands, CA.

Kochert, M.N., and M. Pellant. 1986. Multiple use in the Snake River Birds of Prey Area. Rangelands 8:217-220.

Lehman, R.N. 1999. Raptor electrocution on power lines: current issues and outlook. Unpubl. rep. U.S. Dept. Int., USGS, Forest and Rangeland Ecosystem Science Center, Snake River Field Station, Boise, ID. 15 pp.

Lehman, R.N., L.B. Carpenter, K. Steenhof, M.N. Kochert, and G.S. Kaltenecker. 1998. Prairie falcon abundance, reproduction, and food habits in the Snake River Birds of Prey National Conservation Area--1997. USGS, Forest and Rangeland Ecosystem Science Center, Snake River Field Station, Boise, ID. 27 pp.

Olendorff, R.R., D.D. Bibles, M.T. Dean, J.R. Haugh, and M.N. Kochert. 1989. Raptor habitat management under the U.S. Bureau of Land Management multiple-use mandate. Raptor Res. Rep. 8:1-80.

Pe1lant, M. 1990. The cheatgrass-wildfire cycle--are there any solutions? Pages 11-18 in E.D. McArthur, E.M. Romney, S.D. Smith, and P.T. Tueller, eds. Proceedings--Symposium on Cheatgrass Invasion, Shrub Die-off, and Other Aspects of Shrub Biology and Management. U.S. Dept. Ag., Forest Service, Ogden, UT.

Peters, E.F., and S.C. Bunting. 1994. Fire conditions pre- and post-occurrence of annual grasses on the Snake River Plain. Pages 31-36 in S.B. Monsen and S.G. Kitchen, eds. Proceedings--ecology and management of grasslands. U.S. Dept. Ag., Forest Service, Gen. Tech. Rep. INT-GTR-313.

Steenhof, K., M.N. Kochert, and T.L. McDonald. 1997. Interactive effects of prey and weather on golden eagle reproduction. J. Animal Ecol. 66:350-362.

, L.B. Carpenter, and R.N. Lehman. 1999. Long-term prairie falcon population changes in relation to prey abundance, weather, land uses, and habitat conditions. Condor 101:28-41.

U.S. Department of the Interior. 1979. Snake River Birds of Prey special research report to the Secretary of the Interior. Bureau Land Management, Boise, ID. 142 pp 
1995. Snake River Birds of Prey National Conservation Area draft management plan.

U.S. Dept. Int., Bureau Land Management, Boise, ID. 179 pp.

. 1996. Effects of military training and fire in the Snake River Birds of Prey National Conservation Area. BLM/IDARNG research project final report. U.S. Geol. Surv., BioI.

Res. Div., Snake River Field Station, Boise, ID. 130 pp.

Whisenant, S.G. 1990. Changing fire frequencies on Idaho's Snake River Plains: ecological and management implications. Pages 4-10 in E.D. McArthur, E.M. Romney, S.D. Smith, and P.T .Tueller, eds. Proceedings--Symposium on Cheatgrass Invasion, Shrub Die-off, and Other Aspects of Shrub Biology and Management. U.S. Dept. Ag., Forest Service, Ogden, UT.

Yensen, D.L. 1981. The 1900 invasion of alien plants into southern Idaho. Great Basin Natl. 41:176-183.

. 1982. A grazing history of southwestern Idaho with emphasis on the Snake River Birds of Prey Study Area. Unpubl. rep. U.S. Dept. Int., Bureau Land Management, Boise, ID. $82 \mathrm{pp}$ 
Table 1. Location and characteristics of 19 study segments in and near the NCA.

\begin{tabular}{lllll}
\hline Study Segment & $\begin{array}{l}\text { Location } \\
\text { (County) }\end{array}$ & $\begin{array}{l}\text { Length } \\
(\mathrm{Km})\end{array}$ & $\begin{array}{l}\text { No. of } \\
\text { Poles }\end{array}$ & Habitat Types $^{1}$ \\
\hline
\end{tabular}

$\underline{\text { Border Sites }}$

$\begin{array}{lllll}\text { B-3 } & \text { Elmore } & 2 & 13 & \text { SH, GR, AG } \\ \text { B-5 } & \text { Elmore } & 2 & 22 & \text { AG, GR, SH } \\ \text { B-6 } & \text { Elmore } & 2 & 21 & \text { AG, GR } \\ \text { B-13 } & \text { Elmore } & 2 & 20 & \text { AG, GR } \\ \text { B-15 } & \text { Elmore } & 2 & 21 & \text { AG } \\ \text { B-19 } & \text { Elmore } & 2 & 20 & \text { AG, GR } \\ \text { B-25 } & \text { Elmore } & 2 & 22 & \text { AG, SH, MSG, WT } \\ \text { B-28 } & \text { Elmore } & 2 & 32 & \text { AG, SH, MSG } \\ \text { B-34 } & \text { Elmore } & 2 & 19 & \text { AG, MSG } \\ \text { B-35 } & \text { Elmore } & 2 & 23 & \text { AG, MSG } \\ \text { B-36 } & \text { Elmore } & 2 & 21 & \text { AG, MSG } \\ \text { B-39 } & \text { Elmore } & 2 & 19 & \text { AG, SH, GR } \\ \text { B-41 } & \text { Elmore } & 2 & 20 & \text { AG, MSG } \\ \text { B-48 } & \text { Ada } & 2 & 21 & \text { AG, GR } \\ \text { B-52 } & \text { Elmore } & 2 & 23 & \text { MSG }\end{array}$

$\underline{\text { Interior Sites }}$

Victory

Swan Falls

Bruneau

C.J. Strike
Ada

Ada

Elmore

Elmore
10

3

2.3

15.9
63

30

23

179
$\mathrm{SH}$

$\mathrm{SH}$ MSG GR, SH, MSG

${ }^{1} \mathrm{SH}=$ Shrub; GR = Grass; MSG = Mixed Shrub/Grass; AG = Agriculture; WT = Water. The order habitat codes are presented reflects the relative dominance of each habitat type. 
Table 2. Species and species categories of birds found under distribution lines in the NCA.

\begin{tabular}{lll}
\hline & \multicolumn{2}{c}{ No. Found } \\
Species /Species Category & Sept.-Nov. Dec. Totals
\end{tabular}

\section{$\underline{\text { Border Sites }}$}

Common Raven

American Kestrel

Red-Tail Hawk

Golden Eagle

Northern Harrier

Unidentified Eagle

Unidentified Raptor

Unidentified Bird

Totals

9

5

3

$\begin{array}{lll}2 & 1 & 3 \\ 1 & 1 & 2\end{array}$

1

$-$

-

1

1

3

12

1

1

1

1

1

1

1

3

$\underline{\text { Interior Sites }}$

Common Raven

Barn Owl

Unidentified Hawk

Unidentified Eagle

Unidentified Bird

$\begin{array}{lll}3 & - & 3 \\ 1 & - & 1 \\ 1 & - & 1 \\ 3 & - & 3 \\ 2 & - & 2 \\ 10 & - & 10\end{array}$

Totals

10 
Table 3. Pole design and configuration for 21 3-phase distribution poles where dead birds were found in and near the NCA.

Pole Type and Configuration No. of Poles

$\underline{\text { Pole Position }}$

Tangent

18

Corner

Corner/Deadend

1

2

Total

21

Pole-Top Configuration

Simple Crossarm $\quad 8$

Underbuilt 9

Compact Design 2

H-Frame 2

$\begin{array}{ll}\text { Total } & 21\end{array}$

$\underline{\text { Static Line }}$

Not Present

2

Present

Total

21

$\underline{\text { Additional Hardware }}^{1}$

No Additional Hardware $\quad 8$

Exposed Jumper Wires 7

Pole-Top Switches 2

Fuse Disconnect Switches 3

Transformers 4

Capacitors 1

${ }^{1}$ Does not total to 21 because some pole-top configurations included several types of additional hardware. 


\section{APPENDIX I \\ POWER LINE MORTALITIES IN THE NCA--1999}

\begin{tabular}{|c|c|c|c|c|}
\hline${\frac{\text { Date }^{1}}{28 \text { Sept. Victory (I) }}}_{\text {Study Segment }}{ }^{2}$ & $\frac{\text { Pole \# }}{141}$ & $\frac{\text { Species }^{3}}{\mathrm{UH}}$ & $\begin{array}{l}\text { Cause of } \\
\text { Death }^{4} \\
\text { unk }\end{array}$ & $\begin{array}{l}\quad \text { Description of Remains } \\
\text { Partial skeleton with skull (no } \\
\text { lower mandible), feathers. }\end{array}$ \\
\hline 28 Sept. Victory (I) & 141 & UB & unk & Partial skeleton mixed with above bird. \\
\hline 28 Sept. Victory (I) & 162 & $\mathrm{CR}$ & unk & Skull only (no lower mandible). \\
\hline 29 Sept. Swan Falls (I) & 38 & UB & unk & Partial skeleton. Possible prey remains. \\
\hline 29 Sept. Victory (I) & 135 & $\mathrm{CR}$ & unk & Partial skeleton and feathers. \\
\hline 2 Nov. B-64 & 13 & UR & unk & $\begin{array}{l}\text { Broken skull (no lower mandible), } \\
\text { partial skeleton. }\end{array}$ \\
\hline 3 Nov. B-3 & 521 & UE & unk & $\begin{array}{l}\text { Nearly complete skeleton (no beak or lower } \\
\text { mandible), feathers. }\end{array}$ \\
\hline 3 Nov. B-3 & 521 & UB & unk & Few bones. \\
\hline 3 Nov. B-3 & 518 & UB & unk & Few bones. Possible prey remains. \\
\hline 5 Nov. C.J. Strike (I) & 452 & UE & unk & $\begin{array}{l}\text { Upper portion of skull (no beak or lower } \\
\text { mandible). }\end{array}$ \\
\hline 6 Nov. C.J. Strike (I) & 326 & UE & unk & Partial skeleton, feathers. \\
\hline 6 Nov. C.J. Strike (I) & 319 & $\mathrm{BO}$ & unk & Feathers. \\
\hline 10 Nov. C.J. Strike (I) & 380 & UE & unk & Single bone and single talon. \\
\hline 10 Nov. C.J. Strike (I) & 388B & $\mathrm{CR}$ & unk & Few feathers. \\
\hline 17 Nov. B-5 & 13 & RT & unk & Feathers and partial skeleton. \\
\hline 17 Nov. B-6 & 4B & $\mathrm{CR}$ & unk & $\begin{array}{l}\text { Skull and partial skeleton (no lower } \\
\text { mandible). }\end{array}$ \\
\hline
\end{tabular}




\section{APPENDIX I \\ POWER LINE MORTALITIES IN THE NCA--1999 \\ (continued)}

\begin{tabular}{|c|c|c|c|c|c|}
\hline$\underline{\text { Date }}^{1}$ & $\underline{\text { Study Segment }}^{2}$ & $\underline{\text { Pole \# }}$ & $\underline{\text { Species }}^{3}$ & $\begin{array}{l}\text { Cause of } \\
\underline{\text { Death }}^{4}\end{array}$ & Description of Remains \\
\hline 17 Nov & 7. $\mathrm{B}-6$ & $4 \mathrm{~B}$ & $\mathrm{CR}$ & unk & Skull, feathers, partial skeleton. \\
\hline $21 \mathrm{Nov}$ & ข. $\mathrm{B}-52$ & 2 & UB & unk & Few bones. \\
\hline $27 \mathrm{Nov}$ & . B-25 & 3 & $\mathrm{AK}$ & unk & Few feathers. Male. \\
\hline 3 Dec. & B-52 & 4 & $\mathrm{AK}$ & unk & Part of a wing. Female. \\
\hline $14 \mathrm{Dec}$ & B-48 & 8 & GE & $\mathrm{E}$ & Fresh carcass of adult turned into FWS. \\
\hline $14 \mathrm{Dec}$ & B-665 & $5 \mathrm{~B}$ & RT & unk & Feathers and few bones. \\
\hline 14 Dec. & B-645 & 12 & $\mathrm{NH}$ & unk & $\begin{array}{l}\text { Feathers, skull, partial skeleton (no } \\
\text { lower mandible). }\end{array}$ \\
\hline 27 Dec. & B-39 & 2 & CR & unk & Feathers only. \\
\hline
\end{tabular}

${ }^{1}$ Date found.

${ }^{2} \mathrm{I}=$ Interior site; $\mathrm{B}=$ Border site

${ }^{3} \mathrm{CR}=$ common raven; $\mathrm{BO}=$ barn owl; $\mathrm{RT}=$ red-tailed hawk; $\mathrm{AK}=$ American kestrel;

$\mathrm{GE}=$ golden eagle; $\mathrm{NH}=$ northern harrier; $\mathrm{UB}=$ unidentified bird; $\mathrm{UH}=$ unidentified hawk;

$\mathrm{UE}=$ unidentified eagle

${ }^{4}$ unk = unknown; $\mathrm{E}=$ electrocution

${ }^{5}$ Segment rejected after Idaho Power retrofitted poles in segment. 


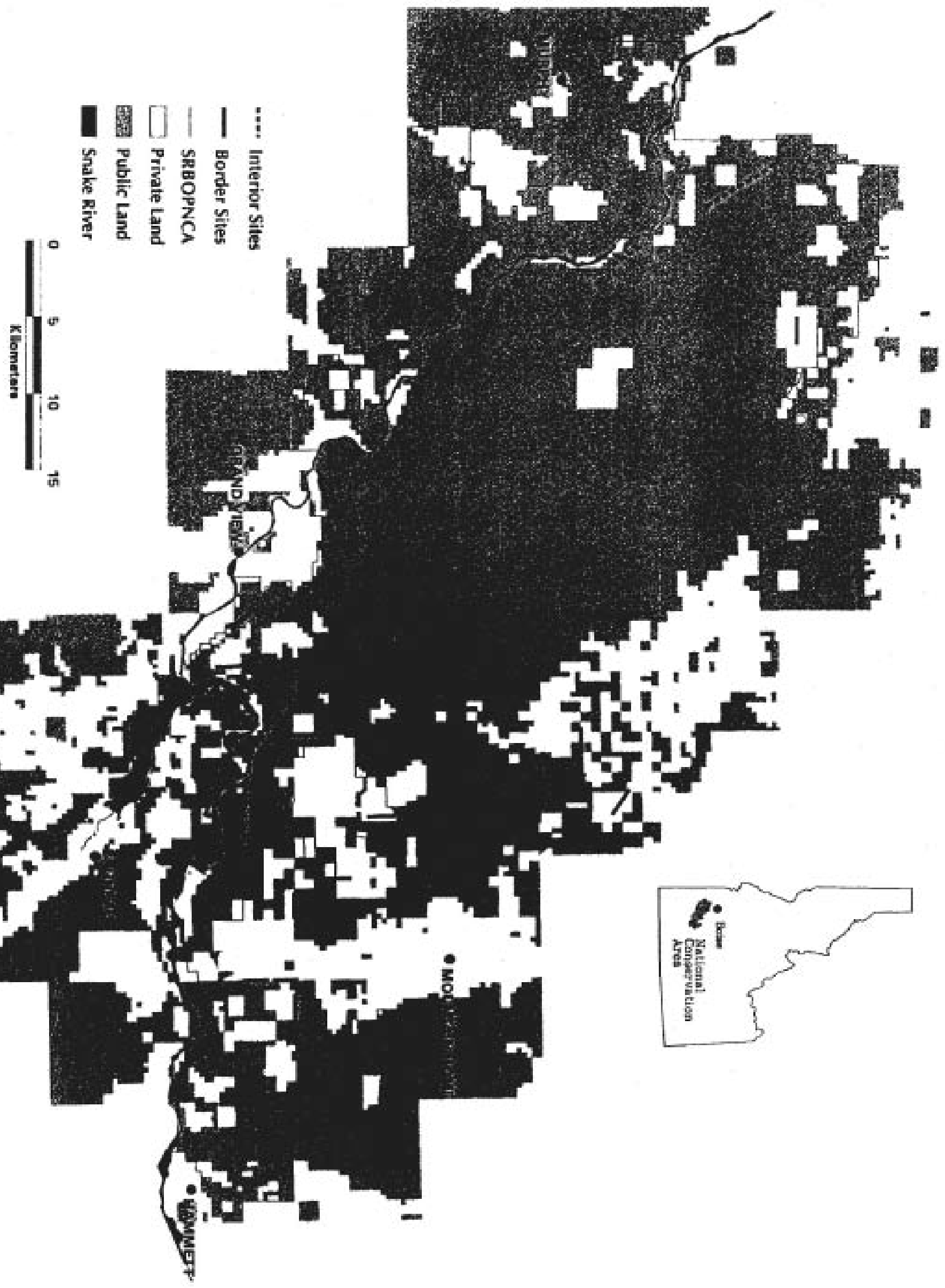

